\title{
Pedro Piñero Ramírez y José Manuel Pedrosa, El romance del caballero al que la muerte aguardaba en Sevilla: Historia, Memoria y Mito, México, Frente de Afirmación Hispanista, 2017, 570 pp.
}

\author{
Gloria Chicote \\ CONICET / IdIHCS, Facultad de Humanidades y Ciencias de la Educación \\ Universidad Nacional de La Plata, Argentina
}

Pedro Piñero y José Manuel Pedrosa nos ofrecen en este libro un exhaustivo análisis del Romance de la muerte del Maestre de Santiago a través de un recorrido por la literatura, la historia, el folklore y la antropología que se extiende desde el siglo XIV hasta el presente y nos entrevera en narrativas múltiples y diversas.

Tal como nos advierte Giuseppe Di Stefano en su Prólogo, el lector de este estudio puede apasionarse con las "narraciones y enredos, con sus sorprendentes afinidades y enlaces, en una geografía y en una cronología sin límites", o puede optar por desentrañar las "modalidades y objetivos de la reelaboración poética de un acontecimiento histórico". Efectivamente, esas son las dos claves de lectura del libro estructurado en cinco partes que dan cuenta de las variaciones literarias sobre el tema, la tradición historiográfica, los motivos recurrentes en su tratamiento a través del tiempo, tales como agüeros, umbrales, celadas y banquetes, las posteriores mitificaciones de los personajes y las conexiones de las poéticas con la política. Este complejo entramado de textualidades pone de manifiesto que el romance no narra meramente un asesinato sino que responde a la conjunción de diferentes motivos folklóricos y literarios que se remontan a los arcanos del mito y de la historia.

El romance se refiere al asesinato de Don Fadrique, perpetrado por su hermanastro, el rey Pedro, en 1358. El hecho es narrado por las crónicas que se escribieron en torno a 1400, entre las que se destaca la del Canciller Pedro López de Ayala, escritas bajo el dominio de la nueva dinastía de los Trastámara, una vez derrocado y asesinado Pedro, y, por lo tanto muy contrarias a su bando. Las crónicas recordaron e interpretaron en clave política el crimen que cantó el romance de un modo muy diferente a como había acontecido y ofrecen varios puntos de referencia que permiten evaluar más cabalmente el modo en que el romance se apartó de la historia para acercarse a los moldes de la literatura folklórica, renunciando a la historicidad, incluso a la verosimilitud, a favor del patetismo. La propaganda antipedrista no solo se extendió a la figura del rey derrocado sino también a su amante y sus familiares, ya que todos ellos constituyen la nobleza desplazada por la dinastía Trastámara. En este sentido, por ejemplo, resulta muy interesante apreciar la focalización en la amante del rey, Doña María de Padilla, demonizada en el romance, pintada como una furia vengativa que lo conduce al asesinato y convertida en bruja en diferentes tradiciones contemporáneas, mientras que en la crónica está descripta como una dama sensible y compasiva. Piñero y Pedrosa señalan con justa razón que este alejamiento de la verdad histórica propiciado por los versos del romance nos indica la preeminencia de la emoción sobre la información en la construcción del discurso poético, en una apuesta estética muy afortunada que le vale al poema su pervivencia hasta nuestros días en diversos formatos como, por ejemplo, el ritual de la cuestación o petición de aguinaldo navideño.

En principio la crítica considera que el romance tiene una cronología temprana, compuesto al calor de los acontecimientos, como uno de los varios poemas que refieren hechos sangrientos del reinado de Pedro, cuando la nueva dinastía de los Trastámara necesitó insistir en el desprestigio del rey que había derrocado. Se destaca especialmente en el estudio de los textos ofrecido por los autores el análisis de la celada mortal tendida a Don Fadrique en clave comparatística con otros textos que ponen en evidencia el vínculo del romance 
particularmente con el acervo folklóricos en y con el conjunto de la literatura universal, entre los que se mencionan situaciones homólogas en los cantares homéricos, el Cantar de los Nibelungos, la dramaturgia de William Shakespeare, o la novelística de Gabriel García Márquez. La celada como motivo narrativo siempre evidencia un enfrentamiento de poderes entre la monarquía y la nobleza o entre diferentes castas, y pone de manifiesto la astucia del poderoso para eliminar a los traidores. A su vez, la celada acude a diferentes recursos que se combinan o reiteran en los textos: las cartas que ordenan al vasallo a presentarse en la corte, la invitación a torneos, la enfermedad fingida del rey, etc. Estos indicios son desatendidos por la víctima, en este caso Don Fadrique, que es un mal traductor de las señales que lo conducen irremediablemente hacia su muerte. Pero en los poemas estudiados el rey asesino también desatiende los avisos del castigo que tendrá su crueldad, ya que pocos años después es asesinado también como consecuencia de una celada que le tiende su otro hermanastro, Enrique, hermano gemelo de Fadrique.

Tiranos asesinos que tienden celadas mortales a sus víctimas confiadas en su hospitalidad tramposa proliferan en la literatura y en la historia. Las páginas del libro recorren hitos de la literatura, muy especialmente de la literatura popular, que denuncian a los reyes tiranos y, en este punto, resulta interesante el nexo que establece el presente estudio entre las poéticas y las políticas. La tradición textual pone en evidencia que la actitud de Pedro no responde a su derecho de ira regia, sino más bien a una furia tiránica que lo lleva a acciones de una crueldad inusitada, para lo cual sirve de ejemplo una síntesis de una de las versiones del romance en la cual Pedro asesina a su hermanastro, come frente a su cadáver, lo entierra con honores en la catedral de Sevilla y sale de viaje a Vizcaya para matar 15 días después a su primo. El encadenamiento de acciones crueles narradas en los poemas tradicionales abre el debate sobre el derecho de resistencia de los súbditos ante situaciones de estado de excepción, desde la perspectiva que varios filósofos contemporáneos como Michel Foucault, Walter Benjamin, o Giorgio Agamben analizaron las reacciones populares ante las formas abusivas de gobierno que tienen la pretensión de convertirse en normas o en normales.

Los poemas nos dicen que Don Pedro fue un maestro de convertir lo criminal en norma y en hacer que el poder enlazase, sin conciencia de contradicción o paradoja, con la abyección. Resulta absolutamente original el planteo que realiza el presente libro al considerar estos textos a la luz de las teorías relativas al poder, a sus representaciones, estrategias y víctimas, a la vez que los conecta con un conjunto de motivos narrativos, tales como las celadas funestas, que fascinaron y continúan fascinando porque quedaron inscriptas en una poética del patetismo. Este enfoque polifónico renueva sustancialmente el acercamiento a un corpus que este estudio completa y sistematiza, a la vez que acompaña con instrumentos críticos de suma utilidad tales como una cronología exhaustiva, una bibliografía crítica muy actualizada y un conjunto de imágenes que nos internan en otros lenguajes estéticos y conceptuales. Todo lo dicho determina que la cuidada edición de 570 páginas nos invite a recorrerlo y disfrutar una vez más estas viejas historias desde renovadas perspectivas teóricas y metodológicas. 